\title{
Pesticides Safety on Food Crops Among Farming Households in Nigeria
}

\author{
Anyim, $\mathbf{A}^{1^{*}}$, Umeh, O. $\mathbf{J}^{\mathbf{2}}$ \\ ${ }^{*}$ Department of Crop Production and Protection, Abia State University Uturu, Abia State, Nigeria \\ ${ }^{2}$ Department of Rural Sociology and Extension, Michael Okpara University \\ of Agriculture, Umudike, Abia State, Nigeria
}

*Corresponding Author: Anyim, A, Department of Crop Production and Protection, Abia State University Uturu, Abia State, Nigeria.

\begin{abstract}
Pesticides can be used to protect food crops against pest damage despite its danger to, humans, livestock and environment. This paper relied on secondary data and information to review the benefits of pesticides usage in food crops, its toxicity and measures necessary for safe food crops production for local consumption and export. Pesticides were found to have a very strong positive impact in the prevention of food crop losses due to insects and other pests in food crops production, thus helping farmers to save money. Also, pesticides were found to give revenue to government through taxes paid by pesticide manufacturers and handlers. It was suggested that to prevent pesticides toxicity only tested, recommended and certified pesticides from proven sources should be used by trained personnel as specified, especially at the economic threshold level. That is, when it is absolutely necessary with adequate precautious. However, pesticides can be safe if they are used carefully as recommended.
\end{abstract}

Keywords: Pesticides, safety, food crops, toxicity

\section{INTRODUCTION}

According to FAO (2007) pesticides are substances or mixture of substances for preventing, destroying, attracting, repelling, or controlling any pest including vectors of human or animal disease, unwanted species of plants or animals causing harm during or otherwise interfering with the production, processing, storage, transport or marketing of food, agricultural commodities, wood and wood products or animal feed stuffs, or substances which may be administered to animals for the control of insects, arachnids or other pests in or on their bodies. The term includes substances intended for use as a plant growth regulator, defoliant, desiccant or agent for thinning fruit or preventing the premature fall of fruit. Also used as substances applied to crops either before or after harvest to protect the commodity from deteriorating during storage and transport. The term normally excludes fertilizers, plant and animal nutrients, food additions and animal drugs(FAO,2007).

Pesticides are clasisified in several ways by the target organisms Controlled, chemical structure (organic, inorganic, synthetic or biological (bio-pesticides) (CSAAMA, 1997) and physical state gaseous-fumigant). The organic pesticides contain the element carbon as a major component. They include Organ chlorines, or chlorinated hydrocarbons, organophosphates, carbonates and synthetic pyrethroids. The inorganic pesticides have no carbon elements (perenox). Pesticides are sometimes classified according to the method of application or method of demonstration, that is, the method of entering the pest organism. For example, baits (Poisoned food substance), spray (applying the pesticide directly on the organism), fumigants (enters the pest organism through the fumes of the pesticides) and systemic poisoning (pesticide is applied through the system of the host).

Pesticides are further classified according to their mode of action on the pest. For example, stomach poison (affect the pest organism in the stomach through the feeding), contact poison (enters the pest through the skin), respiratory poison (interfering with the respiratory system of the pest), nerve poison (affects the nervous system of the organism) and anticoagulants (cause bleeding in the pest externally or internally). Pesticides can be classified based on the form in which they are supplied wettable 
dispersible, granules, wettable powder (WPS), liquid-emulsifiable concentrates (EC), suspension concentrate (SC), capsulated suspension (CS), ready for use aerosols-flit guns and canned sprays.

Further classifications are based on the pesticide toxicity to the test animals, the oral dermal dose to kill $50 \%$ of small animals, commonly rats/fish under test $\left(\mathrm{LD}_{50}\right)$. A pesticide can be extremely toxic, high toxic, moderately toxic and slightly toxic, as the case may be. Pesticides consist of the active ingredient (a.i) and the inactive or inert ingredient. The active ingredient of any pesticide is that part of the formulation that is biologically lethal while the inactive ingredients are needed to make the active ingredient available for ready use by the farmer. The formulation may be wet or dry form.

In Nigeria, it is estimated that crop losses due to pests and diseases of some cultivated crops are within the range of 10-100\% (Table 1). These losses in most cases begin with the sowing of the seed and continue throughout the phases of production, storage and processing. The huge losses attributable to these pests and diseases aggravate the food deficit situation in Nigeria and drastically reduce the financial returns to farmers and their export earnings, hence, the use of pesticides by farmers to protect their crops. Therefore, controlling them will increase food production as well as ensuring food security for our people. However, pesticides, if not properly used, can cause serious problems; foremost among these is toxicity with an estimated 3.000 .000 or more cases of pesticides poison annually, in 20,000 of which proved fatal with yet unknown long term consequences, for humans, wild life and environment (Emeribe, 2008; Anyim and Aghale, 2017).

Table1. Estimates of crop losses due to pests and diseases of the principal food crops in Nigeria.

\begin{tabular}{|c|c|c|}
\hline \multirow{2}{*}{ Crops } & \multicolumn{2}{|c|}{ \% Losses caused by } \\
\cline { 2 - 3 } & Pests & Diseases \\
\hline Cereals & $15-25$ & $10-20$ \\
\hline Grain Legumes & $10-95$ & $10-15$ \\
\hline Root and tubers & $12-90$ & $20-100$ \\
\hline
\end{tabular}

Source: Anyim, 2016

\section{Pesticides Used for Pest Control in Food Crops in Nigeria}

There are three main groups of pesticides commonly used to prevent damages in food crops. These are insecticides, fungicides, and rodenticides (NARELS, 1999; Anyim, 2016) (Table 2).

Table2. Some Pesticides used for pest control in food crops in Nigeria

\begin{tabular}{|c|c|c|c|}
\hline Trade name & $\begin{array}{c}\text { Pesticides group } \\
\text { or } \text { chemical constituent }\end{array}$ & Formulation & Food Crop Protected \\
\hline \multicolumn{4}{|l|}{ Insecticides } \\
\hline Cymbush & Cypermethrin & $\begin{array}{l}\text { Emulsifiable } \\
\text { concentrate }\end{array}$ & Maize, cowpea \\
\hline Decis & Deltamethrin & $\begin{array}{l}\text { Emulsifiable } \\
\text { concentrate }\end{array}$ & $\begin{array}{c}\text { Rice, cowpea, cassava, } \\
\text { soybean }\end{array}$ \\
\hline Furadan & Carbufuran & Dust & Maize, guinea corn, millet \\
\hline Karate & Lambdacyhalothrin & $\begin{array}{l}\text { Emulsifiable } \\
\text { concentrate }\end{array}$ & $\begin{array}{l}\text { Rice, groundnut, cowpea, } \\
\text { millet }\end{array}$ \\
\hline Rogor 40 & Dimethoate $40 \%$ & $\begin{array}{l}\text { Emulsifiable } \\
\text { concentrate }\end{array}$ & Cassava, cowpea \\
\hline Actellic 25EC & Pirimiphos methyl & $\begin{array}{l}\text { Emulsifiable } \\
\text { concentrate }\end{array}$ & Guinea corn, yam, maize \\
\hline $\begin{array}{c}\text { Carbaryl 85/ Sevin 85/ } \\
\text { Vetox } 85\end{array}$ & Carbaryl & $\begin{array}{l}\text { Emulsifiable } \\
\text { concentrate }\end{array}$ & $\begin{array}{l}\text { Guinea corn, yam, maize, } \\
\text { millet, rice, wheat }\end{array}$ \\
\hline \multicolumn{4}{|l|}{ Fungicides } \\
\hline Benlate & Benomyl & Powder & Rice, cowpea, yam, wheat \\
\hline Dithane M45 & Mancozeb 80\% & Powder & Groundnut, cowpea, soybean \\
\hline \multicolumn{4}{|l|}{ Rodenticides } \\
\hline Commando & Zinic Phosphide & Dust & Rice \\
\hline
\end{tabular}

Sources: NAERLS(1999); Anyim (2016) 


\subsection{Insecticides}

The insecticides are usually nerve poisons. There are two main types, namely; Contact and/or Stomach poisons and Respiratory poisons or fumigants. A contact insecticide is a poison which is able to penetrate the insect cuticle and thereby enter the body tissues (Anyim and Aghale, 2017). A fumigant is a gas or vapour which is taken into the insect through its respiratory system (CTA, 1989).

\subsection{Fungicides}

The Fungicides are used to control fungi. They are also poisonous chemical product. However, they are not as readily absorbed into animals as insecticides, because of the dissimilarity between plant and animal systems, cell wall characteristics, tissue compositions, metabolic processes and animal organ functions (NAERLS, 1999). However, when the chemicals are absorbed into animals they cause problem of skin irritation; disrupt respiratory and/or digestive aliments which vary in severity and often from individual. As the animal system attempts to metabolize and excrete these "Foreign chemical", various organs like the Liver, the Kidney and in some cases the nervous system are adversely affected (NAERLS, 1999; Anyim and Aghale, 2017).

\subsection{Rodenticides}

The rodenticides are used to control rodents. They are also poisonous product; the rodenticides are of two kinds, the acute poison and chronic poison. Acute poisons are groups of poisons that can cause quick death if eaten by the rodents in small qualities. Rodents need to eat only a mouthful of poison to die within half an hour. They are extremely poisons (CTA, 1991, Okunade, 2006 and Anyim and Aghale 2017). The Chronic poisons or slow poison on the other hand are poisons that multiple doses have to be taken by rodents before killing them due to its slow action. They are added to food and must be eaten for a number of days before death occurs. They cause rodents to bleed inside their bodies. Bleeding occur from old wounds and their tissues which do not stop (CTA, 1991, Anyim and Aghale, 2017).

\section{Benefits of Using Pesticides in Crop Production}

The benefits are of two types; primary and secondary The primary benefits are the direct gains from the use of pesticides while secondary benefits are effects that are more long term (Cooper and Dobson, 2007, Anyim and Aghale 2017).

\subsection{Primary Benefits}

The primary benefits includes:-

1. Save farmer money by preventing crop losses to pests and diseases (Emeribe, 2008; Amadioha et. al., 2004)

2. It permits more crops varieties to be grown, reduce manpower requirements, mechanical cultivation, saves time, save cost etc (Emeribe, 2008).

3. It enhances crop yields for example, Ogunwolu (1992) found out that insecticides application significantly reduced pod and seed damage and consequently increased the seed yield of cowpea. Similarly, Anyim (2003) found that insecticides significantly increased the yield of soybean with $48 \%$ yield reduction in the farm.

4. Pesticides are used to manage rodents that attack crops in the farm.

\subsection{Secondary Effects}

1. Pesticide usage enhances food availability and security for local consumption and export. Invariably, the nutrition and health of our people will be improved and export revenue increased

2. Government may derive revenue from tax paid by pesticide manufacturers, distributors, dealers, commercial applicators, and farmers to boost internally generated revenue (IGR)

3. Stabilization of national crop production which will in turn shape the national agricultural economy. 


\section{Pesticide Toxicity}

Pesticides are toxic (Poisonous) to all animals. Two types of toxicity are recognized. They are chronic and acute toxicity. The chronic toxicity is the effect of small, non- lethal does received over a long time, resulting in cancer, brain, liver and kidney damage. The acute toxicity is the immediate poisonous effects of a single dose, resulting in nausea, nervous symptoms, and eventual death (TITA, 1995;Anyim, 2013).

Acute toxicity is commonly measured by calculating the $\mathrm{LD}_{50}$ value which is the amount of pesticide (in mg per kg of animal weight) that kills half of a randomly selected population of test animals such as rat, rabbits, and birds. The magnitude of an acute toxic effect depends on how the chemical is applied. Normally, two $\mathrm{LD}_{50}$ values are quoted: Oral (Exposure through mouth) and dermal (exposure through skin) (IITA, 1995: Anyim, 2016). Differences between oral and dermal $\mathrm{LD}_{50}$ values may be large and depends on the chemical and physical properties of the pesticide. Consequently, acute oral $\mathrm{LD}_{50}$ values can be classified as shown in Table 3. Pesticides with an acute oral $\mathrm{LD}_{50}$ of less than $200 \mathrm{mg} / \mathrm{kg}$ should not be used in small scale farming. Table 4 gives examples of $\mathrm{LD}_{50}$ values for some insecticides commonly used in Nigeria.

Table3. Classification of oral toxicity

\begin{tabular}{|c|c|c|}
\hline Class & LD $_{50}(\mathrm{MG} 1 \mathrm{KG})$ & Toxicity \\
\hline $\mathrm{A}$ & $<1$ & Extremely toxic \\
$\mathrm{B}$ & $1-50$ & Highly toxic \\
\hline $\mathrm{C}$ & $50-500$ & Moderately toxic \\
$\mathrm{D}$ & $500-5000$ & Slightly toxic \\
\hline
\end{tabular}

Sources: IITA (1995); Anyim (2013)

Table4. $L D_{50}$ values for some pesticides commonly used in Nigeria $(\mathrm{mg} / \mathrm{kg})$.

\begin{tabular}{|c|c|c|}
\hline Pesticides & Acute oral & Acute dermal \\
\hline Cabofuran & Highly toxic & 10,500 \\
\hline Monocrotophos & 11 & 342 \\
\hline Dimethoate & 20 & 650 \\
\hline Pirimiphos-Methyl & Moderately toxic & $>200$ \\
\hline Cypermethrin & Slightly toxic & $>4800$ \\
\hline
\end{tabular}

Sources: IITA, 1995; Anyim, 2016

\section{Measures Necessary for Safe Food Crops Production}

It is very obvious that pesticides are poisons and can contaminate food crops, cause injury, illness and accidental death if misused(Emeribe, 2008; Amadioha et al.,2004; Miller,2004; Anyim, 2016). Therefore, to avert its adverse-side effects on safe crop production, the following measurers are recommended.

\subsection{Use of Certified Pesticides}

Only pesticides certified by National Agency for Food Administration and control (NAFDAC) and World Health Organization (WHO) should be used. The product label must indicate direction for use, equipment to be used, active ingredient of the product, WHO symbols, warnings, date of manufacture and date of expiration.

\subsection{Establishment of Pesticides Tolerance Levels in Treated Crops}

The tolerance level of the different classes of pesticides must be established at registration, to guide scientists, crop protectionists, pesticides applicators and farmers on the maximum amount of pesticides residue that may legally remain on or in treated crops.

\subsection{Enforcement of Ban on Banned, Restricted and Adulterated Pesticides}

The Consumer Protection Council (CPU) and NAFDAC should intensity efforts to expand their dragnet to ensure that all banned, restricted and adulterated pesticides are not used in crop production. 
Agricultural dealers, farmers or pest control Agents found making or using these products should be prosecuted according to existing laws, if any. Also, all registered pesticides should be renewed every 15 years to ensure they meet the international standard.

\subsection{Initiating Protection at Economic Threshold (ET) Levels}

Under economic conditions, food crops should be protected when it becomes infested with pest at the economic threshold level which is the population density at which control measures should be initiated to prevent pest population from reaching economic injury level (Figure 1). The economic injury level (EIL) is the population density that will cause economic damage while economic damage is the amount of injury which will justify the use of artificial control measures. Consequently, integrated pest management (IPM) which is the use of all suitable and compatible techniques and methods of pest control with the pesticide option as a last resort for safe crop production should be adopted.

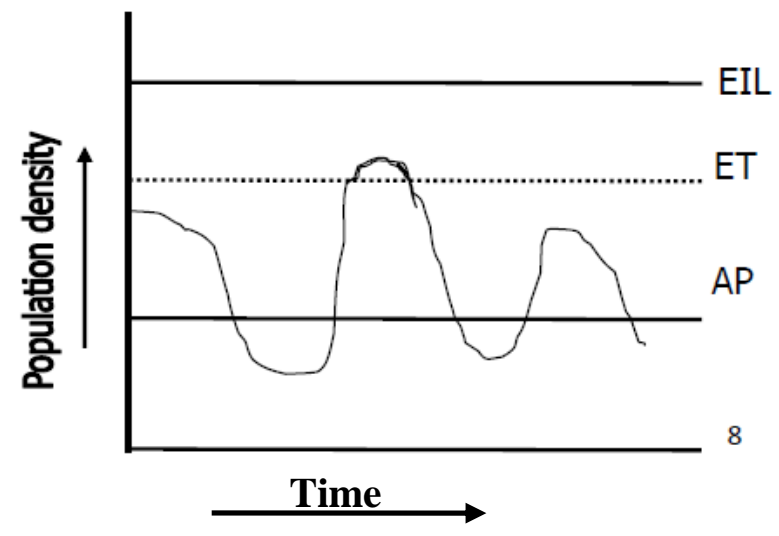

Figure1. Pest population oscillations in a habitat (EIL, Economic injury level, ET, Economic Threshold, AP, Average Population).

\subsection{Mounting of Pesticides Safety Education and Pesticide Applicator Regulation}

The mounting of pesticides safety education and applicator regulation should be pursued vigorously by Government at levels to protect the public from pesticide misuse. Similarly, Government should empower Agricultural Extension Agents and Crop Protectionists to educate farmers and indeed, the public on safe use of pesticides through professional campaigns and publicity.

\subsection{Use of alternatives to synthetic pesticides}

Currently, the use of alternative to synthetic pesticides is being recommend for safe crop production. Miller (2004) noted that alternatives to pesticides are available and include methods of cultivation, use of biological pest control (such as pheromones and microbial pesticides), genetic engineering and methods of interfering with pest breeding. Besides, use of plant extracts has shown potentials and effectiveness in the control of pest of food crops. Amadioha et al (2004) revealed that neem extract controlled Anthracnose disease of cowpea, blast, brown spot sheath blight of rice and the beetle in Okra. Also, leaf extract of Carica papaya controlled powdery meal dew of paper (Amadioha et al, 2004). In some countries like Sweden pesticides usage has best halved with hardly any reduction in crop yield. In Indonesia, farmers have reduced pesticides use in rice fields by 65\% (Miller, 2004).

However, research should be intensified in the development of new classes of safer pesticides across the globe. This is the cornerstone of Integrated Pest Management (IPM) in crop production.

\subsection{Obeying Rules Governing Fumigation in the Field}

The pesticide applicator must obey the following rules before, during and after fumigation in the field.

- Following the instructions on the labels strictly.

- Wearing of protective clothing (high cotton, rubber gloves and boots).

- Measuring pesticides before mixing, but do not use spoons, cups etc normally used in households.

- Keeping other people and animals away from the area when spraying. 
- Never eat, drink or smoke when applying a pesticide.

- If a spray nozzle becomes blocked during use, never blow it clear by mouth.

- Using recommended rates of application religiously.

- Observing safety periods in other to avoid toxic residues on crops at the time of consumption.

- Avoiding drift of pesticides to adjacent crops, livestock, open water and wells.

- Spray, if possible, during the early morning and late afternoon ours.

- Clean the equipment and protective clothing after treatment.

- Empty containers should be buried or burned.

- Wash yourself with soap and water.

\section{CONCLUSION}

The benefits of using pesticides in the control of pest and diseases, its toxicity to life and measures that will ensure safe crop production for local consumption and export were $\mathrm{x}$-rayed. It was observed that pesticides are useful in the protection of feed crops against pest and disease damage. Also, pesticide usage can save farmers by preventing crop losses. It was also observed that pesticides give revenue to government at all levels through taxes paid by pesticide manufacturers, wholesalers and applicators. However, for food crop production for local consumption and export only tested, recommended and certified pesticides from approved dealers must be used why every farmer or consumer should wait for the safety periods before harvesting and consumption of crops treated with pesticides.

Therefore, researchers and crop protectionist should intensify research on the development of new classes of safer pesticides since alternative to the synthetic pesticides have shown great promise and effectiveness in Nigeria.

\section{REFERENCES}

[1] Amadioha, A.C., Nwabeke, P.N. and Obi, V.I. (2004) Principles of crop protection.Totan publishers Limited. P.152-178.

[2] Anyim, A (2013). Pesticides and safe agricultural production. Lead paper presented at the $30^{\text {th }}$ Annual Conference of the Nigeria Society for Plant Protection (NSPP) held at Michael Okpara University of Agriculture, Umudike, Abia state, Nigeria, March 10-14, 2013. 22pp.

[3] Anyim, A. (2003). Effect of insecticidal treatment on the yield and control of major insect pests of soybean Glycine max (L) Merrill) in south-Eastern Nigeria. Int.J. Agric Rural Dev., 2003,4:100-109.

[4] Anyim, A. (2016). Pesticides and safe food crops production in Nigeria. Proceedings of $50^{\text {th }}$ Annual Conference of Agricultural Society of Nigeria (ASN) "Abia 2016" NRCRI Umudike, $3^{\text {rd }}-7^{\text {th }}$ October, 2016 P.465-470.

[5] Anyim,A. and Aghale, D.N.(2017). Review on pesticides safety on stored products in Nigeria. Journal of

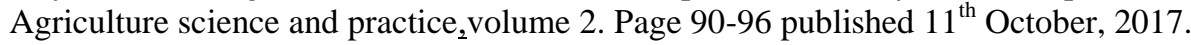

[6] Cooper, J. and Dobson, H. (2007). The benefits of pesticides to mankind and environment. Crop Protection, 26 (9), 1337-1348.

[7] Council in Scientific Affairs, American Medical Association (CSAAMA) (1997). Educational and Informational strategies to reduce pesticides risk Preventive Medicine, 26 (2), 191-200.

[8] CTA (Technical centre for Agricultural and Rural Cooperation)(1989). Pesticides: Compounds, use and hazards. Agrodok, 29, 4-61.

[9] CTA (Technical centre for Agriculture and Rural cooperation)(1991). Protection of stored grains and pulses. Agrodok 18 R.ed. P. 23-43.

[10] Emeribe, E.O. (2008). Safety precautions in the use of pesticides, calibrations and application rates. Paper presented at a one-day sensitization and awareness workshop on safe use of pesticides for Agriculture stakeholders organized by Consumer Protection Council in Abakiliki, June 5, 2008, 28p.

[11] Food and Agriculture organization (FAO) (2007). Programmes: International Code of Conduct on the distribution and use of pesticides. P.95.

[12] International Institute of Tropical Agriculture (IITA) (1995). Safe use of insecticides in agriculture. Research guide 15. Jackai, L.E.N. eds. 40pp. 
[13] Miller, G.T.(2004). Sustaining the Earth, $6^{\text {th }}$ edition. Thompson Learning Inc. California, Chapter 9, P. 211-216.

[14] National Agricultural Extension and Research Liaison Services(NAERLS) (1999). Pesticide usage in Nigeria. Extension Bulletin No.84. 96pp.

[15] Ogunwolu, E.O (1992). Field infestation and damage to soybean and cowpea by pod sucking bugs in Benue State, Nigeria, Insect Science Application, 13 (16): 8901-8905.

[16] Okunade, S.O. (2006). Principles and practices of grain storageChrisking venturesltd. Lagos, Kano, p.25-64.

Citation: Anyim, et.al."Pesticides Safety on Food Crops Among Farming Households in Nigeria"International Journal of Advanced Research in Botany (IJARB), vol. 5, no. 2, pp. 38-44, 2019. http://dx.doi.org/10.20431/2455-4316.0502004.

Copyright: (C) 2019 Authors. This is an open-access article distributed under the terms of the Creative Commons Attribution License, which permits unrestricted use, distribution, and reproduction in any medium, provided the original author and source are credited. 